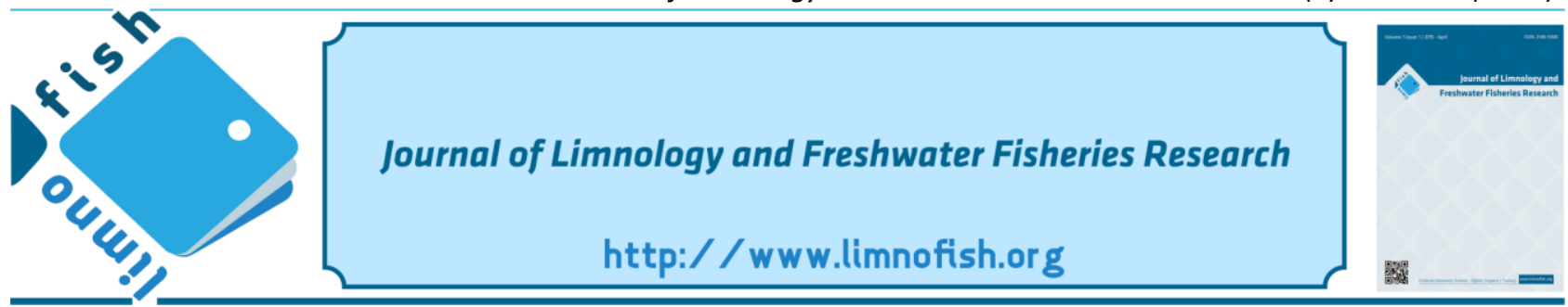

\title{
Comparative Studies on Serum Lysozyme Activities of Common Carp (Cyprinus carpio), Pikeperch (Sander lucioperca), Prussian Carp (Carassius gibelio) and Crayfish (Astacus leptodactylus)
}

\author{
Cafer BULUT $^{1 *}$ (i) Ayșegül KUBílaY ${ }^{2}$ (i) \\ ${ }^{1}$ Fisheries Research Institute, TR-32500 Eğirdir-Isparta, Turkey \\ ${ }^{2}$ Faculty of Eğirdir Fisheries, Isparta University of Applied Sciences, TR-32260, Isparta, Turkey
}

\section{A B S T R ACT}

In this study, serum lysozyme activity was studied by the agar well diffusion assay in various species of fish (common carp, Cyprinus carpio, pikeperch, Sander lucioperca, prussian carp, Carassius gibelio) and crayfish (Astacus leptodactylus) obtained from three different regions in spring and autumn in 2013. The highest levels of lysozyme activity were found in pikeperch fish, followed by common carp, prussian carp, and crayfish, respectively. There was no significant difference between common carp, prussian carp, and crayfish, but it was found a significant between pikeperch fish and the other species $(\mathrm{p}<0.05)$. There was a significant difference of serum lysozyme levels between spring and autumn in common carp, prussian carp and crayfish $(\mathrm{p}<0.05)$. There was no significant difference between seasons in pikeperch fish. These results showed different of the lysozyme activity in the fish innate immune system in the aquatic ecosystem of different species.

Keywords: Innate immunite, stress, seasonal variation, agar well diffusion assay, fisheries

\section{ARTICLE INFO}

\section{RESEARCH ARTICLE}

Received : 03.04.2019

Revised : :17.02.2020

Accepted : : 10.03.2020

Published : 27.08 .2020

DOI:10.17216/LimnoFish.548527

* CORRESPONDING AUTHOR

caferbulut@gmail.com

Phone : +902463133460

Sazan (Cyrpinus carpio), Sudak (Sander lucioperca), Gümüşi Havuz Balığı (Carassius gibelio) ve Kerevit (Astacus leptodactylus) Örneklerinde Serum Lizozim Aktivitelerinin Karşılaştırılması

Öz: Bu çalışmada, ilkbahar ve sonbahar dönemlerinde üç farklı bölgeden elde edilen sazan (Cyprinus carpio), sudak (Sander lucioperca), gümüşi havuz balığı (Carassius gibelio) ve kerevit (Astacus leptodactylus) örneklerinde diffüzyon agar metodu kullanılarak serum lizozim aktiviteleri incelenmiştir. Lizozim aktivitesi en yüksek seviyede sudak balıklarında, ardından sırayla sazan, gümüşi havuz balığı ve kerevit örneklerinde bulunmuștur. Sazan, gümüşi havuz balığı ve kerevit arasında anlamlı bir fark bulunmazken sudak balıkları ve diğer türler arasında anlamlı bir farklılık olduğu belirlenmiştir $(p<0,05)$. Sazan, gümüşi havuz balığı ve kerevitlerde ilkbahar ve sonbahar dönemleri arasında serum lizozim düzeylerinde fark anlamlı bulunurken $(p<0,05)$, sudak balıklarında mevsimler arasındaki fark anlamlı bulunmamıştır. Bu sonuçlar, sucul ekosistemindeki farklı türlerin doğuştan gelen bağışıklık sistemindeki lizozim aktivitesinin farklı olduğunu göstermiştir.

Anahtar kelimeler: Doğal bağışıklık, stres, mevsimsel değişim, difüzyon agar metodu, su ürünleri

How to Cite

Bulut C, Kubilay A. 2020. Comparative Studies on Serum Lysozyme Activities of Common Carp (Cyprinus carpio), Pikeperch (Sander lucioperca), Prussian Carp (Carassius gibelio) and Crayfish (Astacus leptodactylus). LimnoFish. 6(2): 111-119. doi: 10.17216/LimnoFish.548527

\section{Introduction}

Fish and crayfish are interaction with a wide range of pathogenic and non-pathogenic microorganisms in the aquatic environment and thus have complex defense mechanisms for their survival. There is specific and innate immune responses in fish. The innate immune system is considered to be the first line of defense against pathogens in fish and is more important for fish as compared with mammals. Lysozyme is an important part of the nonspecific immune response and is commonly found in invertebrates and vertebrates (Magnadottir et al. 2005; Bowden 2008; Cerenius and Söderhäll 2018). It is known that leukocytes secrete lysozyme in fish (Murray and Fletcher 1976). The kidney has the highest lysozyme activity in fish. Lysozyme level or activity is an important index of innate immunity of fish, due to the high concentration of these leukocytes in the anterior hematopoietic portion of the kidney (Saurabh and Sahoo 2008). Lysozyme is 
an important bacteriolytic agent found in a variety of freshwater and marine fish species (Lie et al. 1989; Balfry and Iwama 2004). Lysozyme has been described in invertebrates as a component of the innate immune system, functioning as an antibacterial protein (Jollès and Jollès 1984; SoteloMundo et al. 2003). Lysozyme is commonly included in the family of the antibacterial peptides based on its small molecular weight and its bacteriolytic effect (Hoffmann and Hoffmann 1990; Boman 1991). It is also known to be opsonic in nature and activates the complement systemand phagocytes. It has been found in mucus, lymphoid tissue serum, other body fluids, and ova of fish (Bowden 2008). Lysozyme has also been detected in many other fish tissues such as spleen, liver, skin, mucus, gills, muscle, ovary and eggs (Takahashi et al. 1986; Lie et al. 1989; Yousif et al. 1991; Takemura and Takano 1995; Karaarslan et al. 2007). Lysozyme isolated from fish is effective as a bacteriolytic agent against both Gram-positive and Gram-negative fish pathogens (Grinde 1989; Yousif et al. 1994). Lysozyme is therefore an important factor in protecting fish against bacterial pathogens, due to its antibacterial properties and because it is located in areas that are in frequent contact with pathogens (i.e. kidney and skin mucus) (Balfry and Iwama 2004).

Lysozyme activity has been shown to vary depending on the sex, state of health, age and size, season, water temperature, $\mathrm{pH}$, toxicants, infections and degree of stressors (Fletcher and White 1973; Fletcher et al. 1977; Möck and Peters 1990; Saurabh and Sahoo 2008; Bulut and Kubilay 2010; Bulut et al. 2012). The genetic variation of lysozyme has also been established (Grinde et al. 1988; Røed et al. 1993; Lund et al. 1995; Balfry et al. 1997) and research into breeding selection programs are being developed that utilize lysozyme activity measurements as selection criteria (Fevolden et al. 1991, 1992, 2002; Fevolden and Røed 1993; Røed et al. 2003; Balfry and Iwama 2004).

The immune response is very sensitive to stress and temperature variations. Hence, both activating and suppressive processes have been described following stress episodes, although the majority of changes often result in deleterious effects. Immediate responses during the activation phase enhance innate humoral immunity such as increased levels of lysozyme and C3 proteins after acute stress (Lie et al. 1989; Sunyer and Tort 1995; Demers and Bayne 1997; Kubilay and Ulukoy 2002; Tort et al. 2004; Tort 2011).

In the present study, it was investigated for serum lysozyme levels in common carp (Cyprinus carpio), pikeperch (Sander lucioperca), prussian carp (Carassius gibelio) and crayfish (Astacus leptodactylus) over a spring/autumn period for seasonal variation.

\section{Materials and Methods \\ Field Sampling of Fish}

Common carp, prussian carp, pikeperch fish, and crayfish used in this study, were obtained from Egirdir Lake in Turkey. Egirdir Lake is the second largest lake in Turkey. The surface area of the lake is approximately $480 \mathrm{~km}^{2}$. The lake is still drinking water sources. In the study Hoyran, Gelendost and Kopru regions were selected as the sampling regions (Hoyran region $\left(38^{\circ} 09^{\prime} 10.64^{\prime \prime} \mathrm{N}-30^{\circ} 45^{\prime} 44.47^{\prime \prime} \mathrm{E}\right.$; Gelendost region $\left.37^{\circ} 59^{\prime} 43.82^{\prime \prime} \mathrm{N}-30^{\circ} 49^{\prime} 10.48^{\prime \prime} \mathrm{E}\right)$ and Kopru region $\left(37^{\circ} 51^{\prime} 41.52^{\prime \prime} \mathrm{N}-30^{\circ} 51^{\prime} 02.18^{\prime \prime} \mathrm{E}\right)$ (Figure 1).

Fish and crayfish samples were obtained in spring and autumn 2013. In the spring and autumn period, 60 fish and 20 crayfish samples were collected in total, 10 from each region. Fish and crayfish samples were caught by nets and pinteres. The length and weights of the fish obtained for analysis are measured. The length, weight, carapace length, and length of the crayfish samples are also noted.

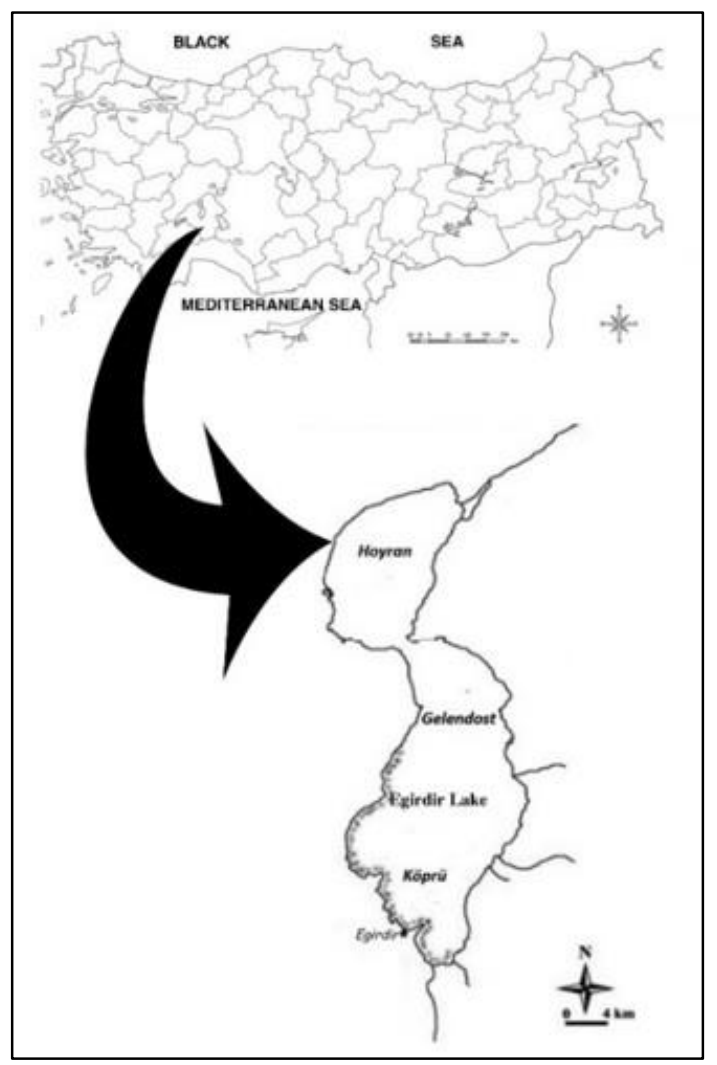

Figure 1. Sampling field of fish and crayfish in Egirdir Lake

\section{Blood collection}

Briefly, fishes and crayfish were anaesthetized using 2-phenoxyethanol. The blood samples were collected by sterile plastic injector from the caudal blood vessels was allowed to clot at room 
temperature for $2 \mathrm{~h}$, then centrifuged at $3000 \mathrm{~g}$ for 15 min. The serum was removed, aliquoted, and frozen at $-20{ }^{\circ} \mathrm{C}$ until required (Figure 2).
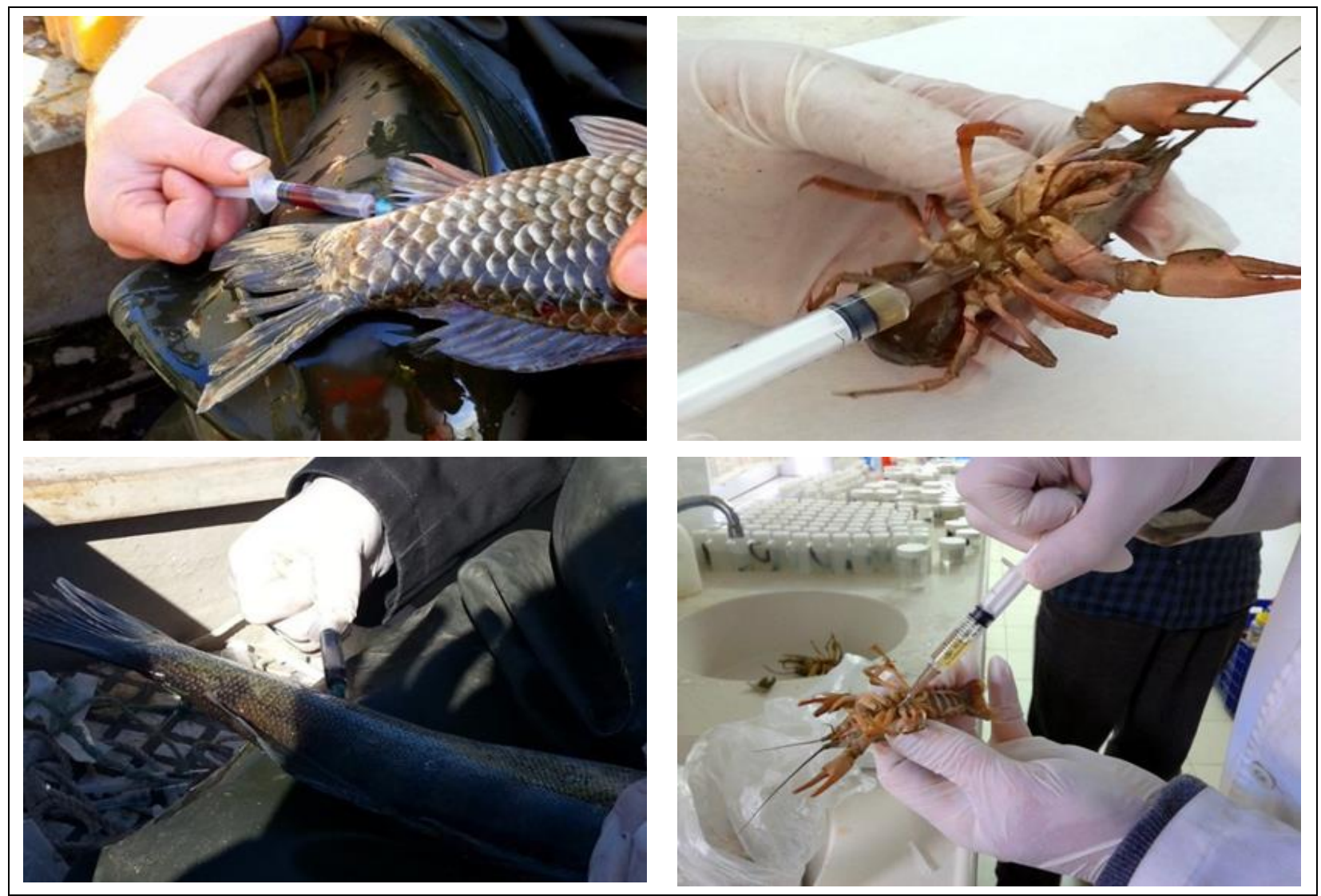

Figure 2. Blood taking from the fish and crayfish

\section{Lysozyme Activity}

Lysozyme activity was determined according to Lie et al. 1989 using a lysoplate assay. Petri dishes containing $1 \%$ agarose in phosphate buffer saline (PBS) pH 6.2 containing $0.60 \mathrm{mg} \mathrm{ml}^{-1}$ liyofilize Micrococcus lysodeicticus (Sigma M 3770) were prepared. Wells of $5 \mathrm{~mm}$ diameter were made in the agarose, filled with $25 \mu \mathrm{l}$ of fish serum, incubated at $25{ }^{\circ} \mathrm{C}$ and the diameter of the lytic zones was measured $24 \mathrm{~h}$ after incubation. The measurements were triplicated (Figure 3). Hen egg white lysozyme (HEWL; Merck EC 3.2.1.27) served as the standard. Sample activity was compared with a calibration curve prepared with chicken egg white lysozyme and activity of serum was calculated based on the activity of commercial HEWL by use of anon-linear regression model, where the area of the lytic zones was in the ordinate and micrograms of HEWL were in Figure 4. Lysozyme activity was measured as a concentration of hen egg-white lysozyme equivalent in $\mathrm{mg} \mathrm{m}^{-1}$ (Grinde 1989; Ellis 1996).

\section{Statistical analysis}

The statistics of the data obtained in the experiments were evaluated using the SPSS package program and Microsoft Excel 2016. Variance analysis (ANOVA) was applied to all the data and the differences between the group averages were determined according to the Duncan test and multiple comparison test and the significance level was $\mathrm{p}<0.05$.

\section{Results}

Size of the fish and the crayfish sample-weight distribution obtained in this study, for common carp fish samples, fork lengths 17.00-66.20 $\mathrm{cm}$ (mean: 33.19 \pm 2.9 ) and the weights were 109-5471 g (mean: 1315 \pm 2.99 ) has been distributed between. For pikeperch fish samples, fork lengths $16.70-44.60 \mathrm{~cm}$ (mean: $30.67 \pm 0.97$ ) and the weights 103-898 g (mean: 337 \pm 29 ) has been distributed between. For prussian carp fish samples, fork lengths $16.00-43.40 \mathrm{~cm}$ (mean: $24.88 \pm 0.46$ ) and the weights 100-986 $\mathrm{g}$ (mean: $429 \pm 18$ ) has been distributed between. For crayfish samples, fork lengths 7.20 to $14.60 \mathrm{~cm}$ (mean: $11.79 \pm 0.19$ ) and the weights 10 to $99 \mathrm{~g}$ (mean: $48 \pm 2$ ) has been distributed between.

The values of common carp, pikeperch, prussian carp, and crayfish lysozyme activity were given in Table 2. The highest lysozyme 
activity was detected in pikeperch $\left(0.944 \mathrm{mg} \mathrm{ml}^{-1}\right)$. prussian carp $\left(0.236 \mathrm{mg} \mathrm{ml} \mathrm{ml}^{-1}\right)$ and crayfish It was followed by common carp $\left(0.256 \mathrm{mg} \mathrm{ml}^{-1}\right)$,

$\left(0.227 \mathrm{mg} \mathrm{ml}^{-1}\right)$, respectively (Figure 5).

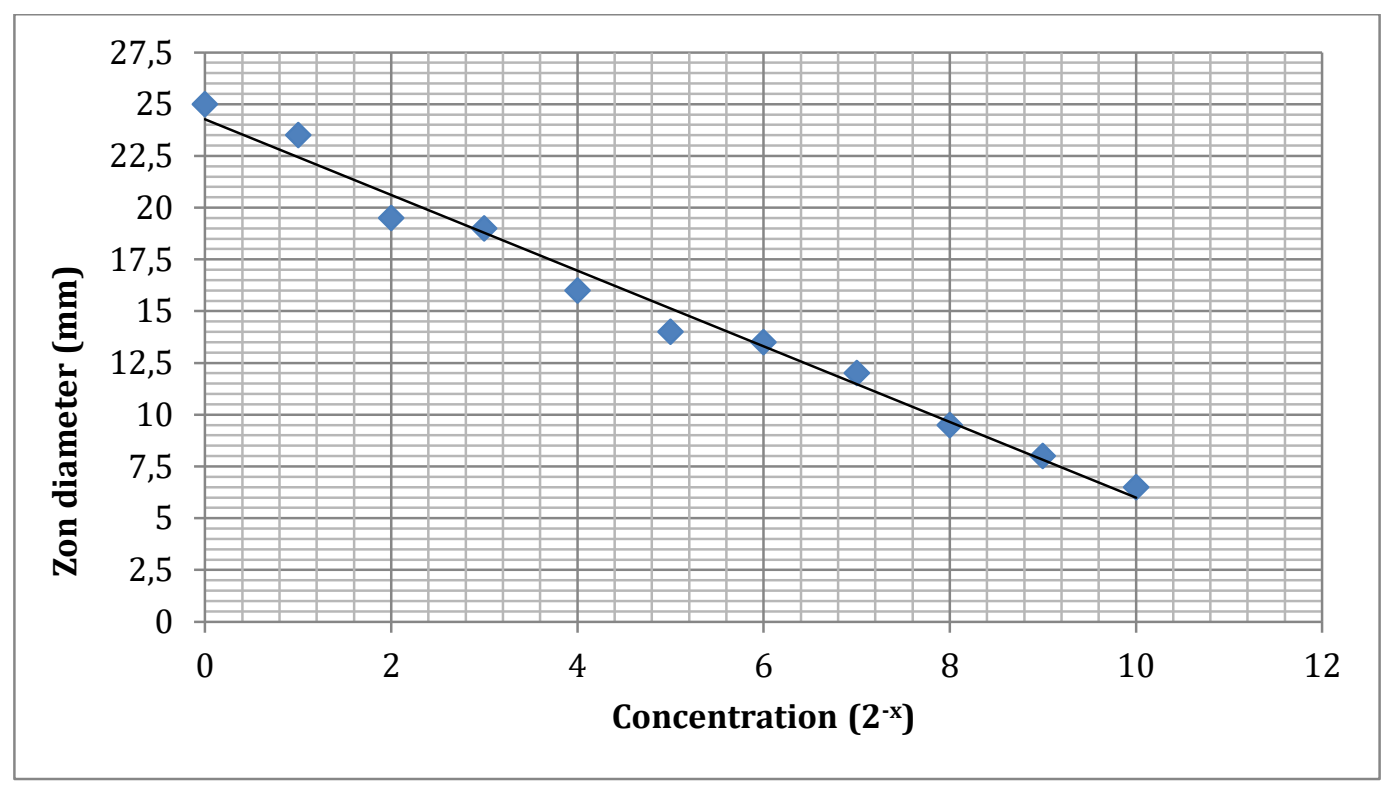

Figure 3. HEWL standard used in lysozyme activity

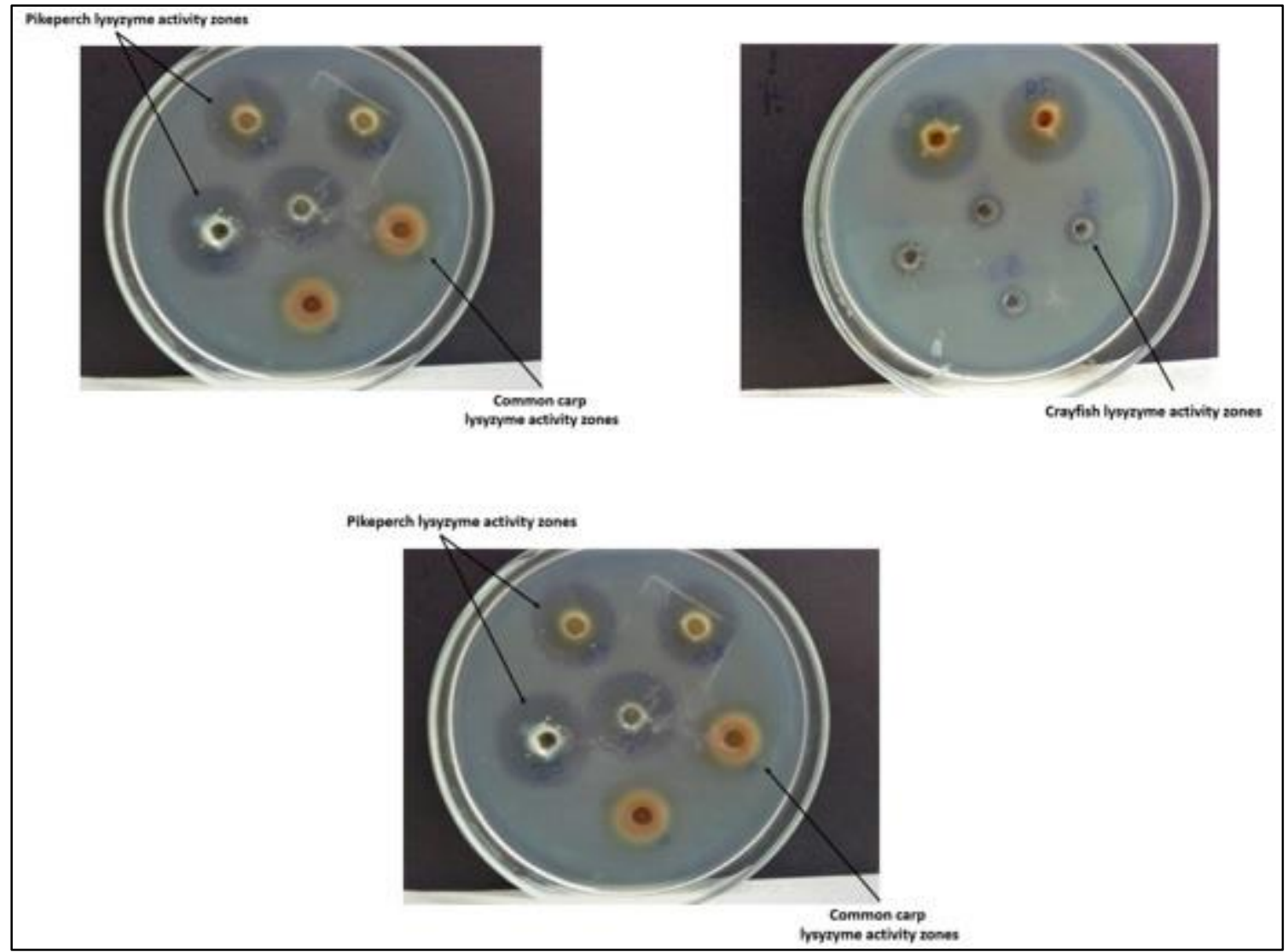

Figure 4. Lysozyme diameters of the common carp, pikeperch and crayfish 


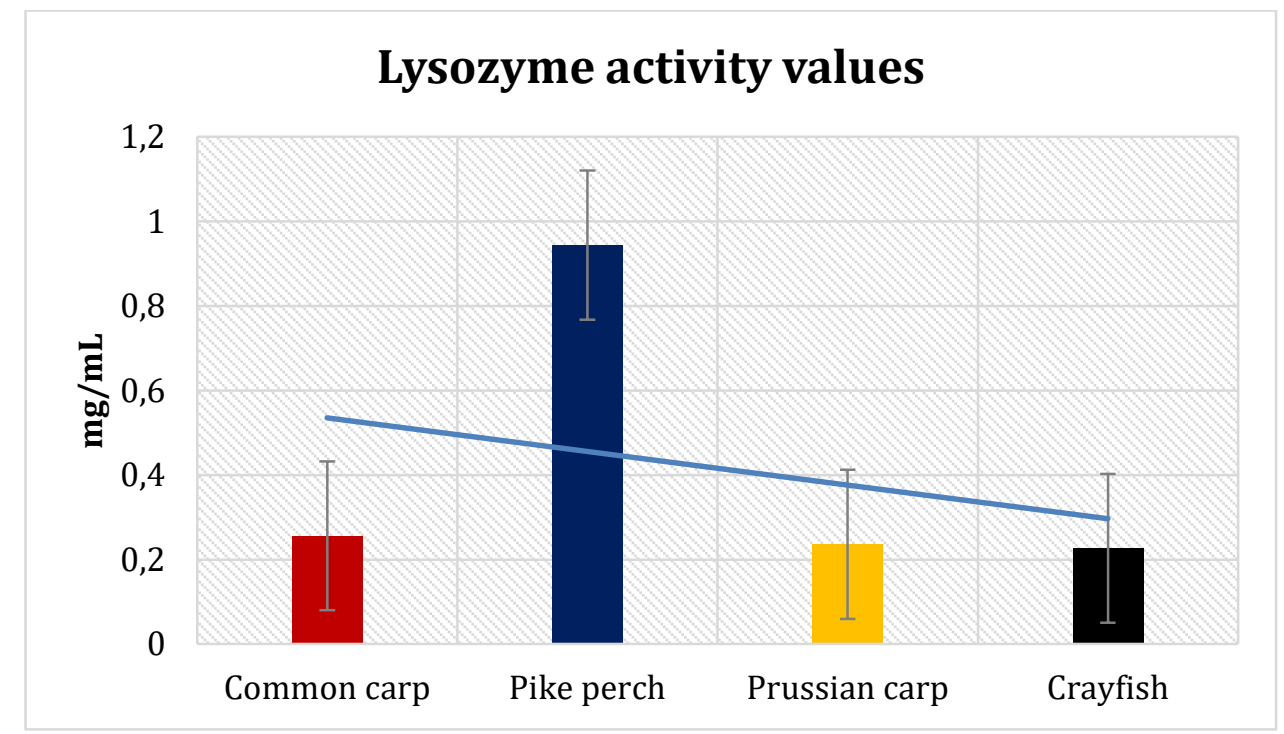

Figure 5. Mean serume lysozyme activity values of common carp, pikeperch, prussian carp and crayfish (mg $\left.\mathrm{ml}^{-1}\right)$

The levels of common carp, prussian carp, and crayfish lysozyme activity were determined in close proximity. The lysozyme activity of pikeperch was found to be quite high compared to other species. This suggests that pikeperch is more sensitive than these species. These results indicate that the pikeperch is more susceptible to stress factors in the aquatic ecosystem.

Serum lysozyme was taken in spring and autumn to see the changes in fish and crayfish under environmental conditions.

Statistical analyzes performed on samples in common carp, statistically significant difference between seasons, as it was observed that there was found to be a statistically significant difference between regions $(\mathrm{p}<0.05)$. In the pikeperch samples, the difference between regions and seasons was not statistically significant $(p<0.05)$. In the prussian carp and crayfish samples, the difference between the regions was not statistically significant and the difference between the seasons was statistically significant $(\mathrm{p}<0.05)$ (Table 1).

The data for the two seasonal samples gave a mean serum lysozyme level of for the sample taken in spring and autumn. Statistical analysis of these two sample sets showed a highly significant difference $(\mathrm{p}<0.05)$.

\section{Discussion}

Fish have functions that can be adapted to survive in aquatic environments (Ingram 1980). Researchers have examined samples of serum, plasma, lymph, kidney, spleen, stomach, gill, gastrointestinal tract, and other organs or tissues in many fish species (Fletcher and White 1973).

Fast et al. 2002; lysosomes have observed differences in enzyme levels between seawater and freshwater-raised fish species, as well as finding a reverse variation in lysozyme-specific activity in rainbow trout, koho salmon and Atlantic salmon. The same researchers have reported that high lysosomal activities in seawater species used in the study may be related to adaptation to species-specific for different environmental conditions and that variations in lysozyme activity are also activities thought to depend on the thickness of the epidermis and the number of mucus cells.

Although many related fish species have been studied for the existence of lysozyme, little is known about the species of hunting fish studied in this study. A significant variation observed in the specific activities of these hydrolytic enzymes between all fish species examined and species of fish within the same family (such as Cyprinidae) appears to differ in terms of prey to animals.

Pickering (1974), Spitzer and Koch (1998); based on their previous reports, they reported that hagfish had a thicker epidermis (95-125 $\mu \mathrm{m})$ than Arctic char $(75.7 \pm 10.2 \mu \mathrm{m})$ and brook trout $(71.0 \pm 6.8 \mu \mathrm{m})$. Also, researchers have reported that hagfish produces mucus in abundance compared to other species studied, suggesting that the hypothesis about epidermal thickness and enzyme activity might be partially valid for hagfish. Balfry and Iwama (2004), reported that changes in lysozyme activity may also be related to a variety of factors such as stress, maturity, diet, gender, species variation, and responses to addressing genetic diversity.

This study showed significant variation in the relative levels of lysozyme between pikeperch and cyprinid species. A significant observation from our study was the higher level of lysozyme in pikeperch. Therefore, levels of lysozyme activity were similarly determined by common carp, prussian carp, and crayfish. The lysozyme activity of pikeperch was found to be quite high compared to other species. 
Table 1. Serume lysozyme activity values in common carp, pikeperch, prussian carp and crayfish $\left(\mathrm{mg} \mathrm{ml}^{-1}\right)$

\begin{tabular}{|c|c|c|c|c|c|c|c|}
\hline \multicolumn{8}{|c|}{ Lysozyme activity $\left(\mathrm{mg} \mathrm{ml}^{-1}\right)$} \\
\hline \multirow{2}{*}{ Season } & & \multicolumn{3}{|c|}{ Common carp } & \multicolumn{3}{|c|}{ Pikeperch } \\
\hline & & Hoyran & Gelendost & Kopru & Hoyran & Gelendost & Kopru \\
\hline \multirow{4}{*}{ Spring } & Min. & 0.171 & 0.171 & 0.171 & 0.798 & 0.798 & 0.856 \\
\hline & Max. & 0.399 & 0.342 & 0.342 & 1.026 & 1.026 & 1.140 \\
\hline & Med. & 0.249 & 0.227 & 0.230 & 0.914 & 0.937 & 0.967 \\
\hline & S.D.* & 0.078 & 0.059 & 0.061 & 0.066 & 0.070 & 0.088 \\
\hline \multirow{9}{*}{ Autumn } & Min. & 0.171 & 0.171 & 0.171 & 0.798 & 0.798 & 0.570 \\
\hline & Max. & 0.399 & 0.399 & 0.456 & 1.140 & 1.026 & 1.140 \\
\hline & Med. & 0.269 & 0.264 & 0.296 & 0.969 & 0.946 & 0.920 \\
\hline & S.D. & 0.061 & 0.080 & 0.100 & 0.125 & 0.077 & 0.170 \\
\hline & & Spring & Autumn & General & Spring & Autumn & General \\
\hline & Min. & 0.171 & 0.171 & 0.171 & 0.798 & 0.570 & 0.570 \\
\hline & Max. & 0.399 & 0.456 & 0.456 & 1.140 & 1.140 & 1.140 \\
\hline & Med. & $0.235^{\mathrm{a}}$ & $0.276^{b}$ & 0.256 & 0.946 & 0.941 & 0.944 \\
\hline & S.D.* & 0.065 & 0.078 & (S.E.) 0.009 & 0.065 & 0.133 & (S.E.) 0.011 \\
\hline \multirow{3}{*}{ Season } & & \multicolumn{3}{|c|}{ Prussian carp } & \multicolumn{3}{|c|}{ Crayfish } \\
\hline & & Hoyran & Gelendost & Kopru & Hoyran & Gelendost & Kopru \\
\hline & Min. & 0.057 & 0.079 & 0.068 & 0.171 & 0.171 & 0.171 \\
\hline \multirow{3}{*}{ Spring } & Max. & 0.285 & 0.342 & 0.342 & 0.342 & 0.570 & 0.456 \\
\hline & Med. & 0.176 & 0.212 & 0.179 & 0.234 & 0.302 & 0.264 \\
\hline & S.D.* & 0.063 & 0.076 & 0.083 & 0.050 & 0.164 & 0.104 \\
\hline \multirow{9}{*}{ Autumn } & Min. & 0.057 & 0.171 & 0.114 & 0.114 & 0.114 & 0.114 \\
\hline & Max. & 0.456 & 0.513 & 0.399 & 0.342 & 0.342 & 0.342 \\
\hline & Med. & 0.262 & 0.282 & 0.265 & 0.219 & 0.211 & 0.211 \\
\hline & S.D. & 0.108 & 0.091 & 0.076 & 0.058 & 0.052 & 0.058 \\
\hline & & Spring & Autumn & General & Spring & Autumn & General \\
\hline & Min. & 0.057 & 0.057 & 0.057 & 0.171 & 0.114 & 0.114 \\
\hline & Max. & 0.342 & 0.513 & 0.513 & 0.570 & 0.342 & 0.570 \\
\hline & Med. & $0.189^{a}$ & $0.268^{b}$ & 0.237 & $0.266^{b}$ & $0.214^{\mathrm{a}}$ & 0.227 \\
\hline & S.D.* & 0.075 & 0.093 & (S.E.) 0.008 & 0.113 & 0.056 & (S.E.) 0.007 \\
\hline
\end{tabular}

* The different letters on the same line show that the difference between the stations is statistically significant $(\mathrm{p}<0,05)$. *S.D.: Standart Deviation;

*S.E.: Standart Error

Lysozyme activity in the pikeperch was at least 4 times greater than cyprinid species. This suggests that pikeperch is more sensitive than these species. These results indicate that the pikeperch is more susceptible to stress factors in the aquatic ecosystem.

Subramanian et al. (2007), reported that they found higher levels of lysozyme in the epidermal cortex (Myxine glutinosa) of the hagfish, in which case the components in the epidermal component of ha hagfish were produced at higher levels. Researchers reported that in the same study, the absence of an advanced immune system could replace the presence of six other high teleosts that the researchers performed. Spitzer and Koch (1998), found that hagfish lives in muddy environments and secretes mucus in abundant quantities. Edwards and Twomey (1982), reported that survival in such an environment may require high levels of these natural immunity factors. Furthermore, changes in trypsinlike protease deficiency, such as Havana fish, live koi carp in muddy habitats, koi carp mucus enzyme levels such as high cathepsin B, and other teleosts, have reported that these species suggest genetic adaptation to various environmental conditions.

Pankhurst (2011), reported that there are limited and very few studies on the stress and the resulting physiological and endocrine effects of fish living in a natural environment with sampling and potential difficulties. However, factors affecting stress in the environmental milieu are gender and maturity, time, nutrition, season, and vital cycle; and that birds living in environmental environments are also causing stress on fish. When we compare the findings with other studies, it is concluded that fishes living on Eğirdir Lake are exposed to less stress than fish living in aquaculture conditions.

Subramanian et al. (2007), reported that they observed a wide variation in enzyme activity among the seven species. The researchers found that only marine fish showed about two times more lysozyme activity than freshwater fish species and that lysozyme activity varied markedly with salinity.

Røed et al. (1993), reported that lysozyme activity varies depending on the species of aquatic 
organisms, health status, stress, sex, season, temperature, and gender maturity. Lie et al. (1989), found that lysosomal activity results in thirteen different species with different outcomes between species, which in turn resulted in the genetic makeup of living things. Fevolden et al. (1999) reported that the level of lysozyme decreased with increasing acute strut predominant over time, while the level of lysozyme declined with longer survival or chronic stratification. Karaarslan et al. (2007), examined the activity of rainbow trout in kidney, spleen, liver, a fertilized egg, and blood serum at different stages in their study. In rainbow trout, lysozyme activity was determined as kidney, liver, blood serum, and spleen, respectively.

Cnaani et al. (2004), Oreochromis aureus, and Oreochromis mossambicus reported that glucose concentration and lysozyme activity received different responses to stress.

A full characterization of the kinetics of change of lysozyme activity as a component will require further research.

There is little analysis of lysozyme activity related to fish species living in the natural environment. Further studies focusing on the factors that influence the production of these innate immune and stress components will provide a better understanding of their roles and the immune system of evolutionarily diverse fish on the aquatic ecosystem.

\section{References}

Balfry SK, Shariff M, Iwama GK. 1997. Strain differences in non-specific immunity of tilapia Oreochromis niloticus following challenge with Vibrio parahaemolyticus. Dis Aquat Organ. 30:77-80. doi: $10.3354 /$ dao030077

Balfry S, Iwama GK. 2004. Observation on the inherent variability omeasuring lysozyme activity in coho salmon (Oncorhynchus kisutch). Comp Biochem Phys B. 138(3):207-211. doi: 10.1016/j.cbpc.2003.12.010

Boman HG. 1991. Antibacterial peptides-key components needed in immunity. Cell. 65(2):205-207. doi: 10.1016/0092-8674(91)90154-q

Bowden TJ. 2008. Modulation of the immune system of fish by their environment. Fish Shellfish Immun. 25(4):373-383. doi: 10.1016/j.fsi.2008.03.017

Bulut C, Kubilay A. 2010. Farklı İşletmelerdeki Gökkusağı Alabalıklarının (Oncorhynchus mykiss) Lizozim Aktivitelerinin Karşılaştırılması. Süleyman Demirel Üniversitesi Fen Bilimleri Enstitüsü Dergisi. 14(2):134-143.

Bulut C. Kubilay A, Akçimen U, Ceylan M. 2012. Formaldehit $\left(\mathrm{CH}_{2} \mathrm{O}\right)$ 'in Farklı Konsantrasyonlarının Gökkuşağı Alabalıklarında (Oncorhynchus mykiss)
Kortizol, Glikoz ve Lizozim Aktivitesi Üzerine Etkileri. Journal of Fisheries Sciences. 6 (4): 321-330. doi: 10.3153/jfscom.akdeniz006

Cerenius L, Söderhäll K. 2018. Crayfish immunity Recent findings. Dev Comp Immunol. 80:94-98. doi: 10.1016/j.dci.2017.05.010

Cnaani A. Tinman S, Avidar Y, Ron M, Hulata G. 2004. Comparative study of biochemical parameters in response to stress in Oreochromis aureus, Oreochromis mossambicus and two strains of Oreochromis niloticus. Aquac Res. 35(15):14341440. doi: 10.1111/j.1365-2109.2004.01167.x

Demers NE, Bayne CJ. 1997. The immediate effects of stress on hormones and plasma lysozyme in rainbow trout. Dev Comp Immunol. 21(4):363-373. doi: 10.1016/S0145-305X(97)00009-8

Edwards EA, Twomey K. 1982. Habitat suitability index models: Common carp. Washington: Fish and Wildlife Service $38 \mathrm{p}$.

Ellis AE. 1996. Lysozyme assay. In: Stolen JS, Fletcher TC, Anderson DP, Roberson BS, Mulswink, WB, editors. Techniques in fish immunology. Fair Haven, USA: SOS Publications. p. 101-105.

Fast MD, Sims DE, Burka JF, Mustafa A, Ross NW. 2002. Skin morphology and humoral non-specific defence parameters of mucus and plasma in rainbow trout, coho and Atlantic salmon. Comp Biochem Phys A. 132(3):645-657. doi: 10.1016/S1095-6433(02)00109-5

Fevolden SE, Refstie T, Røed KH. 1991. Selection for high and low cortisol stress response in Atlantic salmon (Salmo salar) and rainbow trout (Oncorhynchus mykiss). Aquaculture. 95(1-2):53-65. doi: 10.1016/0044-8486(91)90072-F

Fevolden SE, Refstie T, Røed KH. 1992. Disease resistance in rainbow trout (Oncorhynchus mykiss) selected for stress response. Aquaculture. 104(12):19-29. doi: 10.1016/0044-8486(92)90134-7

Fevolden SE, Røed KH. 1993. Cortisol and immune characteristics in rainbow trout (Oncorhynchus mykiss) selected for high or low tolerance to stress. $\mathbf{J}$ Fish Biol. 43(6):919-930. doi: 10.1111/j.1095-8649.1993.tb01166.x

Fevolden SE, Røed KH, Fjalestad KT, Stien J. 1999. Poststress levels of lysozyme and cortisol in adult rainbow trout: heritabilities and genetic correlations. $\mathbf{J}$ Fish Biol. 54(4):900-910. doi: 10.1111/j.1095-8649.1999.tb02040.x

Fevolden SE, Røed KH, Fjalestad KT. 2002. Selection response of cortisol and lysozyme in rainbow trout and correlation to growth. Aquaculture. 205(1-2):61-75. doi: 10.1016/S0044-8486(01)00660-3

Fletcher TC, White A. 1973. Lysozyme activity in the plaice (Pleuronectes platessa L.). Experientia. 29:1283-1285. doi: 10.1007/BF01935119

Fletcher TC, White A, Baldo BA. 1977. C-reactive protein-like precipitin and lysozyme in the 
lumpsucker Cyclopterus lumpus L. during the breeding season. Comparative Biochemistry and Physiology Part B: Comparative Biochemistry. 57(4):353-357.

doi: 10.1016/0305-0491(77)90066-9

Grinde B, Jollès J, Jollès P. 1988. Purification and characterization of two lysozymes from rainbow trout (Salmo gairdneri). Eur J Biochem. 173(2):269-273. doi: 10.1111/j.1432-1033.1988.tb13994.x

Grinde B. 1989. Lysozyme from rainbow trout (Oncorhynchus mykiss), as an antibacterial agent against fish pathogens. J Fish Dis. 12(2):95-104. doi: 10.1111/j.1365-2761.1989.tb00281.x

Hoffmann JA, Hoffmann D. 1990. The inducible antibacterial peptides of dipteran insects. Res Immunol. 141(9):910-918. doi: 10.1016/0923-2494(90)90192-2

Ingram GA. 1980. Substances involved in the natural resistance of fish to infection - A review. J Fish Biol. 16(1):23-60.

doi: 10.1111/j.1095-8649.1980.tb03685.x

Jollès P, Jollès J. 1984. What's new in lysozyme research? Always a model system, today as yesterday. Mol Cell Biochem. 63:165-189. doi: 10.1007/BF00285225

Karaarslan G, Kabak T, Çakır B, Kubilay A. 2007. Gökkuşağı alabalığı (Oncorhynchus mykiss)'nın iç organ, kan serumu ve döllenmiş yumurtalarında lizozim aktivitesi. Paper presented at: IV. Ulusal Su Günleri; Antalya, Turkey.

Kubilay A, Uluköy G. 2002. The Effects of Acut Stress on Rainbow Trout (Oncorhynchus mykiss). Turk J Zool. 26(2):249-254.

Lie Q, Evensen Q, Sørensen A, Frøysadal E. 1989. Study on lysozyme activity in some fish species, Dis Aquat Organ. 6:1-5. doi: 10.3354/dao006001

Lund T, Gjedrem T, Bentsen HB, Eide DM, Larsen HJS, Røed KH. 1995. Genetic variation in immune parameters and associations to survival in Atlantic salmon. J Fish Biol. 46(5):748-758. doi: 10.1111/j.1095-8649.1995.tb01598.x

Magnadottir B, Lange S, Gudmundsdottir S, Bøgald J, Dalmo RA. 2005. Ontogeny of humoral immune parameters in fish. Fish Shellfish Immun. 19(5):429439. doi: 10.1016/j.fsi.2005.03.010

Möck A, Peters G. 1990. Lysozyme activity in rainbow trout, Oncorhynchus mykiss (Walbaum), stressed by handling, taransport, and water pollution. J Fish Biol. 37(6):873-885. doi: 10.1111/j.1095-8649.1990.tb03591.x

Murray CK, Fletcher TC. 1976. The immunohistochemical localization of lysozyme in plaice (Pleuronectes platessa L.) tissue. J Fish Biol. 9(4):329-334. doi: 10.1111/j.1095-8649.1976.tb04681.x

Pankhurst NW. 2011. The endocrinology of stress in fish: an environmental perspective. Gen Comp Endocr. 170(2):265-275.

doi: 10.1016/j.ygcen.2010.07.017
Pickering AD. 1974. The distribution of mucus cells in the epidermis of the brown trout Salmo trutta (L.) and the char Salvelinus alpinus (L). J Fish Biol. 6(2):111-118. doi: 10.1111/j.1095-8649.1974.tb04531.x

Røed KH, Fjalestad KT, Stromsheim A. 1993. Genetic variation in lysozyme activity and spontaneous haemoltic activity in Atlantic salmon (Salmo salar). Aquaculture. 114(1-2):19-31. doi: 10.1016/0044-8486(93)90247-V

Røed, KH, Fevolden SE, Fjalestad KT. 2003. Disease resistance and immune characteristics in rainbow trout (Oncorhynchus mykiss) selected for lysozyme activity. Aquaculture. 209(1-4): 91-101. doi: 10.1016/S0044-8486(01)00810-9

Saurabh S, Sahoo PK. 2008. Lysozyme: an important defence molecule of fish innate immune system. Aquac Res. 39(3):223-239. doi: 10.1111/j.1365-2109.2007.01883.x

Sotelo-Mundo RR, Islas-Osuna MA, de-la-Re-Vega E, Hernández-López J, Vargas-Albores F, YepizPlascencia G. 2003. cDNA cloning of the lysozyme of the white shrimp Penaeus vannamei. Fish Shellfish Immun. 15(4):325-331. doi: 10.1016/S1050-4648(02)00176-6

Spitzer RH, Koch EA. 1998. Hagfish skin and slime glands. In: Jørgensen JM, Lomholt JM, Weber RE, Malte H, editors. The Biology of Hagfishes. London: Springer Netherlands. p. 109-32.

Subramanian S, MacKinnon SL, Ross NW. 2007. A comparative study on innate immune parameters in the epidermal mucus of various fish species. Comp Biochem Phys B. 148(3):256-263. doi: 10.1016/j.cbpb.2007.06.003

Sunyer JO, Tort L. 1995. Natural hemolytic and bactericidal activities of sea bream Sparus aurata serum are effected by the alternative complement pathway. Vet Immunol Immunop. 45(3-4):333-345. doi: 10.1016/0165-2427(94)05430-Z

Takahashi K, Mori K, Nomura T. 1986. Occurrence and characterization of lysozyme from marine bivalves. B Jpn Soc Sci Fish. 52(5):863-868. doi: $10.2331 /$ suisan. 52.863

Takemura A, Takano K. 1995. Lysozyme in the ovary of tilapia (Oreochromis mossambicus): its purification and some biological properties. Fish Physiol Biochem. $14: 415-421$. doi: $10.1007 / \mathrm{BF} 00003379$

Tort L. 2011. Hormonal responses to stress | Impact of stress in health and reproduction. Reference Module in Life Sciences Encyclopedia of Fish Physiology. 2:1541-1552. doi: 10.1016/B978-0-12-374553-8.00191-X

Tort L, Rotllant J, Liarte C, Acerete L, Hernandez A, Ceulemans S, Coutteau P, Padros F. 2004. Effects of temperature decrease on feeding rates, immune indicators and histopathological changes of gilthead sea bream Sparus aurata fed with an experimental diet. Aquaculture. 229(1-4):55-65. doi: 10.1016/S0044-8486(03)00403-4

Yousif AN, Albright LJ, Evelyn TPT. 1991. Occurrence of lysozyme in the eggs of coho salmon 
Oncorhynchus kisutch. Dis Aquat Organ. 10:45-49. doi: 10.3354/dao010045

Yousif OM, Alhadrami GA, Pessarakli M. 1994.

Evaluation of dehydrated alfalfa and salt bush (Atriplex) leaves in diets for tilapia (Oreochromis aureus L.). Aquaculture. 129(3-4):341347.

doi: 10.1016/0044-8486(94)90050-7 